Catherine Moon

Boston College

School of Theology and Ministry

\title{
Kierkegaard in the Garden: The Interiority of God's Wonder and Praise
}

Is there an interior aesthetic? Can each and every human being turn inward and behold a beauty and nobility that leads them to the face of God? Or are aesthetics a purely outward manifestation of the beauty and order that points to the ultimate Creator? Soren Kierkegaard in his Concluding Unscientific Postscript asserts that human beings can only attain truth through inwardness and that this motion inward "at its highest in an existing subject is passion; to passion there corresponds truth as a paradox. ${ }^{1 "}$ In this essay, using the response to creation God sets forth in Genesis and Kierkegaard's conception of passionate inwardness I plan to explore the relationship between beauty and wonder and how their interplay might yield the highest truth, so that by means of the aesthetic one cannot not only see God or His attributes, but abide in Him through His Love.

To begin, the term aesthetic typically applies to objects of sight, however in its most complete signification aesthetic can refer to any sense experience. Creation is often considered the aesthetic mediation by which God reveals Himself to humanity and is thereby called natural revelation. In this way it is clear that the aesthetic of creation occasions wonder such that wonder is the impetus for human questioning. It begins the quest for meaning, for truth, for God. But, is this outward objective mediation necessary for human beings to perceive the fullness of God's

${ }^{1}$ Kierkegaard, Søren, Swenson, David F. , Tr, American-Scandinavian Foundation, and Lowrie, Walter. Kierkegaard's Concluding Unscientific Postscript. Princeton: Princeton University Press, for American Scandinavian Foundation, 1941, 177 
beauty and nobility? Or is it simply nonsensical to try to understand the aesthetic apart from external sense experience? I posit that the term interior aesthetic is not asinine or nonsensical, but indicative of an essential paradox that we must grasp in order to understand the full scope of our vey humanity. For "Socratically, the knower was someone who existed, but now [with respect to Christianity] someone who exists has been marked in such a way that existence has undertaken an essential change in him... It [is] by eternal truth's relating to the one who exists that the paradox [comes] about."2 This is to say that humanity does not transcend to God by means of the objective, but God descends to humanity by means of the subjective. God operates internally in us and individually not so that we might lose ourselves in His self-revelation or grace, but so that we might find ourselves and finally be set free. In this way, God's revelation is necessarily an aesthetic experience. Therefore, although sense experience is inherently subjective, it need not be relativistic so long as through the subjective movement absolute truth, the universal can be attained.

In Genesis, God epitomizes the act of attaining a universal through the subjective when He "saw that it was good." The subjectivity of God's sense of

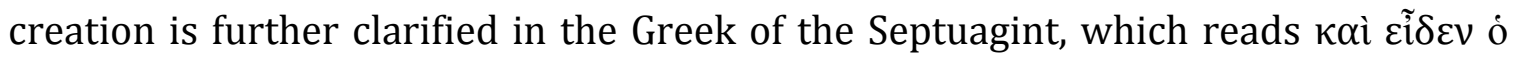

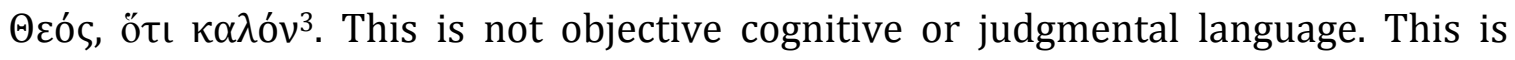
aesthetic language. The word $\varepsilon i \tilde{\delta} \varepsilon v$ translated above as saw is the same verb that would have been used to describe the action of the human eye. $\gamma \iota \gamma v \omega ́ \sigma \kappa \omega$ the word for to know which even carries with it a meaning of intuitive perception rather than

\footnotetext{
2 Ibid, 174

${ }^{3}$ Brenton, Lancelot Charles Lee. The Septuagint with Apocrypha : Greek and English. Grand Rapids, Mich.: Zondervan, 1980.
} 
sense perception would have offered a more concrete logical way of displaying that the ordered whole was good. Such an impersonal, matter-of-fact expression might even seem fitting of the immutable omniscient God. And yet despite God having no eyes and being Being itself the author chooses a word that denotes sense experience. This forces us the audience to view God not as a banal metaphysical abstract, but subjectively in His passionate personhood. God in His personhood is not the impenetrable Prime Mover, but the Triune Lover, Beloved, and Bond of Love that abides in whomever abides in Him. ${ }^{4}$ God's subjectivity is further emphasized by the word $\kappa \alpha \lambda$ óv, translated above as good because it carries with it an aesthetic connotation. Yes, in the neuter $\kappa \alpha \lambda$ óv can most certainly mean good, but traditionally it is translated as beautiful or noble. It can even mean dear or beloved when set in conjunction with a person, which harkens back to our understanding of God's self-relation. There is nothing sterile or indifferent or objective about this kind of sense perception God is recounted as having with respect to creation.

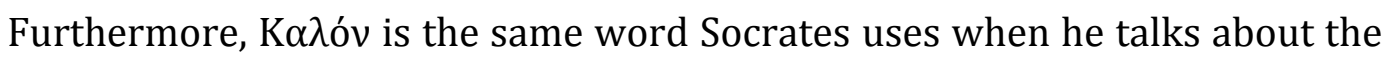
form of The Good. This word connects God to the philosopher, to the passionate response of wonder that arises in the human being from the aesthetic, from beholding anything that participates in the $\kappa \alpha \lambda$ óv, the Good, the Beautiful, the Noble. Were wonder the sole impetus for human questioning, we might be forced to start calling God the philosopher, however it is a restless wonder that governs the philosopher and forces him to seek self-understanding. The human being cannot

${ }^{4}$ John 4:16 
look into creation and find its fulfillment. In this way, wonder thrusts humanity into its incompletion, forcing it to inhabit its mutability and finitude.

In what way are we then to understand God as possessing wonder? When "God saw that the light was good" after bringing the heavens and the earth into being, did he see that in the way that humans who wonder at nature see His goodness, as a mediation of Himself? Or is this our first example of an interior aesthetic? As I stated earlier, God is Being and encompasses the whole of existence. Therefore, He could not simply look outside of Himself in order to behold His existent creation. God is His own mediation, He is the means by which goodness and beauty can be known. To look at creation is for God to look into Himself. It is only through perceiving goodness, beauty, and nobility in Himself that God can sense the goodness of His own creation. This is necessarily an interior motion for God because He is His own end and complete in Himself. It is for this reason that wonder is not incomplete for Him in the way it is for human beings although it did initiate the same process. The aorist tense of the verb cĩ $\delta \varepsilon v$ reflects and further characterizes this completion because God is not tied down to any ongoing temporality or to any two precise moments in time as he would have been were the imperfect or perfect tenses used. In the way the meaning of $\varepsilon \tilde{i} \delta \varepsilon v$ signifies God's subjectivity, the tense of the word affirms God's perfection. From God we learn that wonder in its perfect state is an inward absolute passionate beholding; wonder in fulfillment abides in the Truth and rests in God's self-relation that bond of love between the Father and Son. 
By what means then do we imperfect, latent human beings attain fulfillment in wonder? How are we to attain the Truth without forever being condemned to the clouds? If the interior aesthetic of God is His self-relation, then what can we understand the interior aesthetic of the human to be? Must God's self-revelation be a mediated sense experience for human beings or can it be begotten directly?

According to Soren Kierkegaard, "to be a Christian is something so deeply reflected that it does not admit of the aesthetical dialectic which allows one man to be for others something he is not for himself." ${ }^{5}$ Here Kierkegaard is using aesthetic in a limited way to underscore the insufficiency of sense experience, which when understood in its most shallow sense gives way to complete relativism or skepticism. This is why "talk of subjectivity, inward-ness...begins as follows: Subjectivity is untruth... objectivity is truth."' Such an understanding of subjectivity and objectivity is rightly concerned with the fallibility of the human senses and the imperfection of the material that might be mediating something higher than itself. For how can God, who did not look outside Himself, but within Himself to see the goodness of his creation ever, be fully encapsulated in it? How are we to trust any sense experience or feeling that arises in us through our decaying flesh enough to say God has fully revealed Himself to humanity? It is for this reason that "Passion and reflection are generally exclusive of one another." However, let us not forget that "it is retrogression to become objective; and even he who is lost through

\footnotetext{
${ }^{5}$ Kierkegaard, 583

${ }^{6}$ Ibid, 173
} 
passion has not lost so much as he who lost passion"7 because God, the Creator, the ultimate truth and light is not only subjective, but subjectivity itself. This could not be made clearer than in the person of Jesus Christ in whom "the eternal truth has come about in time. " ${ }^{8}$ Christ incarnate is the essence of that paradox that we must seize hold of with respect to interior aesthetic. The complete inwardness of God becomes embodied in human flesh, possesses a bodily aesthetic. But Christ's body gains transcendence through his love, through his unwavering passion for inward unity with the divine, while still finite and we gain transcendence in his bodily sacrifice. Paradox is not only the crux of making the interior aesthetic sensible; but paradox is the crux of Christianity.

In conclusion, as previously stated, subjectivity is that place in a human being's most inward depths; from [which] proceeds the life of love, for "from the heart proceeds life." ${ }^{9}$ Our God is a personal God, whose essence is Love, ${ }^{10}$ which makes "the thing of being a Christian...not determined by the what of Christianity but by the how of the Christian."11 Interiority is the means by which God works in us and the aesthetic we must seize hold of in that interiority is love. As an image of God each one of us possesses the capacity to wonder, marvel at beauty and the fulfillment of this wonder and beauty is love. Love is the interior aesthetic by which

\footnotetext{
7 Ibid

${ }^{8}$ Kierkegaard 177

${ }^{9}$ Soren Kierkegaard, Works of Love, Harper Perennial Modern Classics, 2009. 26 10 John 4:8

${ }^{11}$ Kierkegaard.Concluding Unscientific Postscript.587
} 
"everyone born of God overcomes the world" 12 and are finally alive to and set free in it.

${ }^{12}$ John 5:4 